\title{
The Exchange Data Communication System based on Centralized Database for the Meat Industry
}

\author{
Yuichi Kobayashi Member (Hitachi, Ltd., yuichi.kobayashi.ma@hitachi.com) \\ Yoji Taniguchi Member (Hitachi,Ltd., yoji.taniguchi.rf@hitachi.com) \\ Shuji Terada Non-member (Hitachi, Ltd., shuji.terada.kw@hitachi.com) \\ Norihisa Komoda Senior Member (Osaka University, komoda@ist.osaka-u.ac.jp)
}

Keywords : Traceability, EDI, Internet Data Center, Exchange data, Code conversion

We propose applying the EDI system that is based on centralized database and supports conversion of code data to the meat industry. In the meat industry, the exchange data shared between companies has included an individual identification number, a sending company code, a receiving company code, item code, producing district, etc.

Fluctuation of the number of offices of the meat industry is larger than value of all the food industries and also the office code converts whenever necessary. Although a standard code is used when introducing EDI system generally, it is difficult to change immediately the entire company original codes in the meat industry to a standard code. And the code map for code conversion must also be registered again.

We adopt the system that converts both original codes directly among companies with reference to a code map, without using a standard code to the meat industry. And we also adopt the customized tool that supports making a code map in the meat industry.

Fig. 1 shows the process of the code direct conversion system.

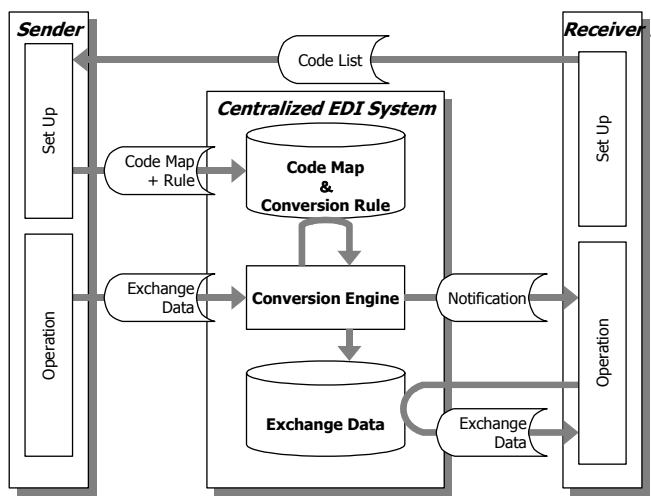

Fig. 1. Code direct conversion function
The supplier makes code map which matched both supplier's code structure and customer's code structure. The code map consists of a name for conversion, a code before conversion, a code after conversion, and conversion conditions to each code. The conversion conditions decide the complicated relation of both code structures uniquely using the attribute information on the exchange data. This system converts exchange data of supplier according to the code map, and sends it to customer.

The tool that supports making a code map is equipped with the form which inputs the code before conversion and the code after conversion, and the condition setting option which makes many to many code conversion possible. Fig. 2 shows the graphical user interface for registering a code map.

This system that mounted these functions has been implemented in September 2004. Twelve enterprises including retailers, and processing traders, and wholesalers were using the system as of June 2005. Although the user is increasing now, the number of code maps is less than the theoretical value.

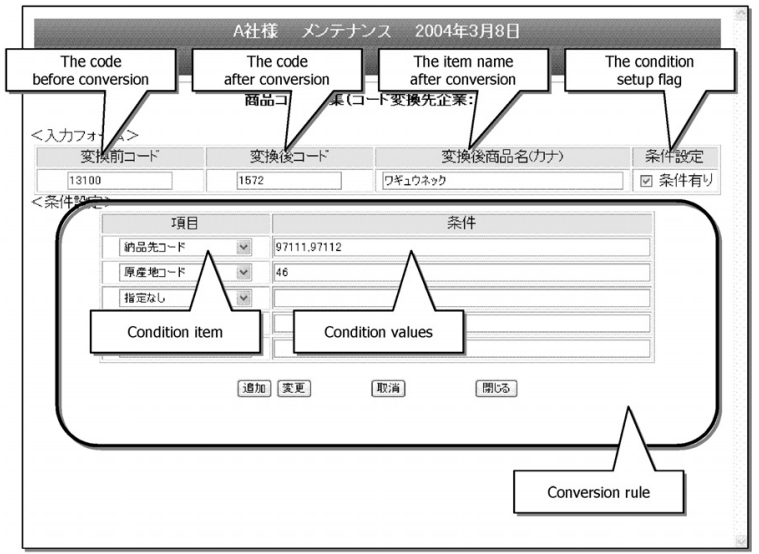

Fig. 2. Code conversion rule registration 


\title{
食肉業界向けデータセンタ型取引情報伝達システム
}

\author{
正員 小林 雄一* \\ 正員谷口 洋司** \\ 非会員 寺田 修司 $* * *$ 上級会員 薦田 憲久****
}

\section{The Exchange Data Communication System based on Centralized Database for the Meat Industry}

Yuichi Kobayashi*, Member, Yoji Taniguchi**, Member, Shuji Terada***, Non־member, Norihisa Komoda****, Senior Member

We propose applying the EDI system that is based on centralized database and supports conversion of code data to the meat industry. This system makes it possible to share exchange data on beef between enterprises from producers to retailers by using Web EDI technology. In order to efficiently convert code direct conversion of a sender's code to a receiver's code using a code map is used. This system that mounted this function has been implemented in September 2004. Twelve enterprises including retailers, and processing traders, and wholesalers were using the system as of June 2005. In this system, the number of code maps relevant to the introductory cost of the code conversion function was lower than the theoretical value and were close to the case that a standard code is mediated.

キーワード : トレーサビリティ, EDI, データセンタ, 取引情報, コード変換

Keywords : Traceability, EDI, Internet Data Center, Exchange data, Code conversion

\section{1. はじめに}

近年，食肉業界では牛海綿状脳症（BSE）問題や産地を 偽り出荷する牛肉偽装事件などから安全性に対する信頼確 保が世界各国で求められている(1)(2)。国内では, 牛の個体識 別情報の適切な管理及び伝達, 提供を促進するために, 2003 年 6 月に「牛の個体識別のための情報の管理及び伝達に関 する特別措置法」（通称「牛肉トレーサビリティ法」）が公 布された。この法律では, 牛肉加工業者, 卸業者, 倉庫事 業者, 小売業者などの流通段階に属する企業に対して, 取

\footnotetext{
* 株式会社日立製作所 システム開発研究所 干244-0817 神奈川県横浜市戸塚区吉田町 292 Hitachi, Ltd., Systems Development Laboratory 292 Yoshida, Totsuka, Yokohama, Kanagawa 244-0817

** 株式会社日立製作所 生産技術研究所

干244-0817 神奈川県横浜市戸塚区吉田町 292

Hitachi, Ltd., Production Engineering Research Laboratory

292 Yoshida, Totsuka, Yokohama, Kanagawa 244-0817

*** 株式会社日立製作所トレーサビリティ・RFID 事業部

干212-8567 神奈川県川崎市幸町鹿島田 890

Hitachi, Ltd., Tracing\&Tracking Systems Division 890 Kashimada, Saiwai, Kawasaki, Kanagawa 212-8567

****大阪大学大学院情報科学研究科

干565-0871 大阪府吹田市山田丘 2-1

Graduate School of Information Science and Technology, Osaka

University, 2-1, Yamada-oka, Suita, Osaka 565-0871
}

引先毎に仕入れた牛の個体識別番号や重量などの情報を伝 達し, 記録, 保存することを義務付けている(3)。しかし, 食 肉業界では紙の伝票を用いた取引が主流であり, 伝票の受 信側ではオペレータが伝票を読みシステムに入力している 場合が多い。したがって, 牛肉トレーサビリティ法や食の 安全・安心への消費者ニーズがもたらす業務負荷が増加す るため, 個体識別番号などを含めた取引情報を伝達するた めの環境を早急に整備することが求められている(4) (6)。

このような状況下では, 紙の伝票による処理負荷を軽減 するために, 企業間で交わされる情報を電子化し, 情報に 対して標準の形式やコード体系を用い, 専用回線やインタ 一ネットを利用して電子化した情報を伝達する EDI (Electronic Data Interchange) システムの適用が有効であ る(7)。さらに, 牛肉トレーサビリティ法の適用範囲は, 食肉 の流通に関わる全ての企業に及ぶため, 牛肉業界では同時 に多数の企業が共有し利用可能なデータセンタ型の EDI シ ステムが望まれる(8)(9)。なぜならデータセンタ型であること により, 各一企業に対するシステム導入費や運用費を分配 し削減可能であるため, 情報化が進んでいない企業も比較 的容易に利用可能となるからである(10)。

実際に EDI システムを導入する上では, 取引情報に含ま れる社内コード体系を取引先コード体系に変換する機能が 
非常に重要となることがわかる。従来, 食肉業界に関わる 多くの企業は，独自のコード体系を築いており，取引情報 を作成する際には，取引先のコード体系に合わせて逐次変 換している。この企業独自のコード体系は，流動性があり， かつ独自性が強いため, 全ての企業のシステムに食肉業界 標準のコード体系を導入することは非常に困難である。し たがって, 現時点では各企業は独自のコード体系で運用す ることとなり, 企業間のコードの変換処理は避けられない という問題がある。

本論文では，各企業がコード体系を取引相手のコード体 系に変換するコード直接変換方式を採用したデータセンタ 型 EDI システムを食肉業界に適用し，実稼働実績に基づき その有用性を示す。

\section{2. 取引情報伝達システムの食肉業界への適用}

〈2·1〉 取引情報伝達システムの機能要件 日本の食 肉業界は，大手食肉メーカ 4 社が市場の $70 \%$ を占めている ことから, 食肉業界の各企業は, 少なくとも大手メ一カ 4 社の内，少なくとも 1 社と提携していると考えられる。取 引情報伝達システムを食肉業界に適用するにあたり，企業 間の提携が多くあることを前提とする。このような食肉業 界では，取引情報伝達システムに対して，「取引情報伝達機 能」および「取引情報一括収集機能」の二つの機能要件を 満たすことが求められている。

取引情報伝達機能とは, 牛肉トレーサビリティ法に対応 するために個体識別番号を含めた取引情報を取引先に伝達 する機能である。売り手側がインターネット網を利用して 取引情報をシステムに登録し，買い手側に通知することに より, 取引した牛肉の個体識別番号や重量などの伝達義務 をサポートする。また, 買い手側は牛肉の入荷前に, 入荷 する牛肉の情報を事前に取得し, 入荷準備や検品時におけ る, 牛肉の個体識別番号単位による整合性確認の可能性が 求められている。

取引情報一括収集機能は，各事業者から収集した取引情 報を，それらの事業者を統括する本部へ一括送信する機能 である。牛肉業界では, しばしば牛肉生産業者, 牛肉加工 業者, 卸業者など複数の業者と提携する企業が存在する。 この機能は，企業の本部に対して，提携する業者が扱う全 ての牛肉に関する取引情報を提供する。例えば, 卸業者が 商品を食肉加工業者から仕入れ, 卸業者の商品として小売 業者に販売するとき, 卸業者を経由せずに直接小売業者に 送る場合でも，卸業者は個体識別番号を含めた取引情報の 確認可能性が求められている。また, 牛肉の在庫管理を倉 庫事業者に委託し, 卸業者や小売業者に販売するとき, 倉 庫事業者から販売先に送る場合でも，個体識別番号を含め た入出庫情報の確認可能性が求められている。

〈2·2〉 取引情報伝達システムの構成上述した取引 情報伝達システムの機能要件を満たすと考えられるデータ センタ型 EDI システムの構成を図 1 に示す。本システムは, 牛肉の個体識別番号や重量などの情報を含む取引情報を各

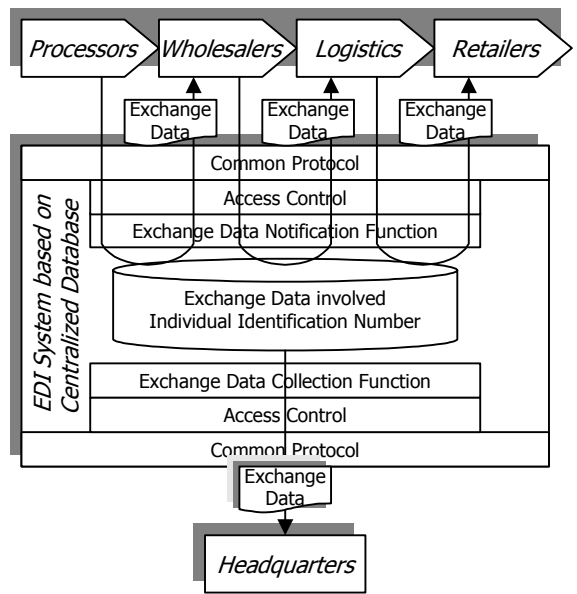

図 1 データセンタ型 EDI システム

Fig. 1. EDI System based on centralized database

企業から収集, 蓄積し, 要求に応じて取引情報を取引先や 本部に提供する。さらに, 取引情報を伝達する企業のシス テム導入コストおよび運用コストを軽減するためにデータ センタ型を採用する。

また，アクセサビリティとセキュリティを考慮して，共 通プロトコルと, アクセス制御機能を備える。汎用的で共 通的なプロトコルは, 食肉業界に関わる様々な事業者が接 続し, 取引情報の伝達を目的とし, XML をベースとするの が一般的である。アクセス制御機能は, 企業グループや取 引関係の情報を含む会員情報を管理し, 本システムへの不 正アクセスや，取引外への情報漏えいを防止する。

〈2·3〉 システムを実現するための課題＼cjkstart取引情報に は企業コードや商品コードが含まれるが，各企業で扱うコ 一ド体系は異なる場合が多く, そのまま取引情報を伝達し ても解釈できない。従来, 売り手側が買い手側のために作 成する取引情報は，オペレータによって注文票や出荷実績 票から参照されシステムに入力される。このとき取引情報 のフォーマットや企業部課コード, 商品コードなどのコー ド体系は, 売り手側と買い手側のコード対応表を参照し, 買い手側のコードに随時変換されている。これに対して, 財団法人食品流通構造改善促進機構により, 食肉の標準商 品コードと EDI 標準メッセージの開発が, 1997 年度から開 始され，2000 年に標準化された(11)。しかし現状では，この 標準は普及しておらず，多くの企業間では従来どおりに買 い手側のコード体系に変換している状況である。標準が普 及しない主な理由は, 食肉業界特有のコード体系の流動性 と独自性によるものと考えられる。

流動性とは, 小売業者では, 常に商品開発が行われ, 次々 と新しい商品コードが生まれるため固定のコード体系を持 たないということを指す。また，表 $1^{(12)}$ に示すように畜産 食料品製造業の事業所数の増減幅は, 食料品製造業全体の 值と比較しても大きく, 事業所コードも随時変化する。

独自性とは，小売業者を始めとする食肉に関わる企業の 中には, 食肉以外の商品も扱っている企業が多く, これら 
表 1 産業事業所数

Table 1. Establishments by industry

\begin{tabular}{|l|r|r|}
\hline & Stockbreeding Maker & \multicolumn{2}{|c|}{ Food Maker } \\
\hline $\begin{array}{l}\text { Number of } \\
\text { establishments }\end{array}$ & 2,979 & 52,211 \\
\hline Newly-organized & $11 \%$ & $7 \%$ \\
\hline Abolished & $14 \%$ & $12 \%$ \\
\hline
\end{tabular}

Example 1

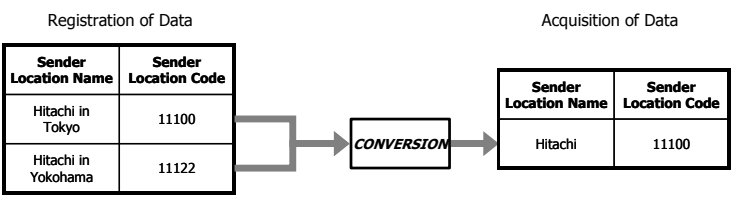

Example 2

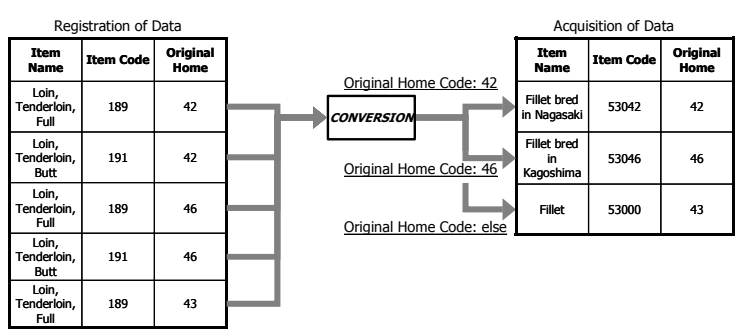

困 2 コード体系混在問題

Fig. 2. Problem of the code confusion

の企業は，扱う商品をまとめて社内で統一のコード体系と したいという要求があるということを指す。

このように，食肉業界では，各企業が独自のコード体系 を持っているため, 企業間で取引情報を伝達するためには, コードマップを作成し，それを参照してコード変換しなけ ればならない。自社のコード体系と対応するコード体系が 一対一の関係であれば，コードマップは比較的容易に作成 できる。しかし実際は, 一対多, 多対一, 多対多の関係が 存在するため, このコード体系混在問題は複雑化している。

牛の個体識別番号を含む取引情報では，企業ごとに一対 多, 多対一, 多対多の対応になる独自コード体系が頻繁に 使われている。例えば図 2 の例 1 に示すように，取引情報 の送信者である売り手の事業所コードについて, 売り手で ある送信者側は，東京事業所コードを“11100”，横浜事業 所コードを“11122”というように所在地ごとに管理してい るのに対して，買い手である受信者側は，東京事業所も横 浜事業所も同一のコード“11100”で管理している。

また, 図 2 の例 2 に示すように, 商品コードについて, 売り手である送信者側は, 牛肉の生産地とは関係なくテン ダーロインをフル “ $189 ”$ と，バット“ $191 ”$ というように 分けて, 生産地は商品コードと別の項目で管理しているの に対して，買い手である受信者側は，牛肉の生産地が長崎 “42”なら “53042”，鹿児島 “46”なら “53046”，その他 なら“53000”というように，テンダーロインをフルとバッ トに区別せず生産地ごとに管理している。
取引情報伝達システムを実現するためには，このコード 体系混在問題を解決しなければならない。

\section{3. コード直接変換方式に基づく取引情報伝達シ ステム}

〈3·1〉 コード体系共有化方式 コード体系混在問題 への対策として「業界標準コード対応方式」,「標準コード 仲介変換方式」および「コード直接変換方式」の三つの方 式が考えられる(13)。

（1）業界標準コード対応方式: 現在各企業で利用されて いる独自コードを，標準コードに移し換える方式である。 すべての企業がこの標準コードを利用することで，コード 変換が必要なくなるため, コード変換にかかる労力の削減 が可能である。

（2）標準コード仲介変換方式: 各企業の独自コード体系 を一旦標準コードに変換する方式である。企業で管理する 独自コードを標準コードに関連付けるだけで良く, 必要と なるコードマップが少ないのが特徵である。

（3）コード直接変換方式: 取引し合う二つの企業ごとに コードを変換する方式である。売り手と買い手が直接取り 決めてコードマップを作成することで, より正確なコード 変換を実現できるのが特徴である。

2 章で述べたように, 食肉業界特有のコード体系の流動性 と独自性により，食肉業界では業界標準コード対応方式の 採用は非常に困難であると考えられる。従って，標準コー ド仲介変換方式と, コード直接変換方式の二つの方式に対 して，食肉業界のニーズの把握や，コード変換の導入コス トを見積もり，一方の方式を採用することにする。

コード変換の導入コストを見積もる上で，標準コード仲 介変換方式とコード直接変換方式に対し，コードマップを 新規に作成するコストの割合を求め比較する。コードマッ プを新規に作成するコストは，システム全体で必要となる コードマップの数を求め, その值から抽出する。ここでは, 牛肉業界における流通段階を, 肉加工業者, 卸業者, 小売 業者の三段階に分け，隣り合う段階の企業間ごとに取引関 係があるモデルを想定する。

標準コード仲介変換方式を導入する場合, 各企業は自社 コード体系と標準コード体系を対応付けるコードマップを 一つずつ準備する必要がある。従って，システム全体で必 要となるコードマップ数 $M_{1}$ は, 企業数 $n$ を用いて次の式の ように表すことができる。

$$
M_{1}=n
$$

コード直接変換方式を導入する場合，各企業は自社コー ド体系と取引先のコード体系を対応付けるコードマップを 準備する必要がある。システム全体で必要となるコードマ ップ数を求めるに, 次の二点について考慮する必要がある。

（1）食肉業界には, 多数の売り手と, 少数の買い手とい った企業数の偏りがあること。

（2）業界全体として，提携企業間の取引が多く，提携し 
ている一つの企業グループとのみ取引する企業が少なくな いこと。

上記二点を考慮しつつ, システム全体で必要となるコー ドマップ数 $M_{2}$ は, 企業数 $n_{1}, n_{2}$, 売り手側及び買い手側企 業の総数に対する売り手側企業数の割合 $\alpha$, 売り手側企業 の総数に対する同時期に複数の買い手側企業と取引する売 り手側企業数の割合 $\beta$ を用いて次の式のように表す。

$$
M_{2}=\alpha(1+\beta) n_{1}+\alpha(1+\beta) n_{2}
$$

ここで, $n_{1}$ は上流側の肉加工業者と卸業者の総数として, $n_{2}$ は下流側の卸業者と小売業者の総数とする。 $n$ と $n_{1}, n_{2}$ の関係は, 次の二式で表すことができるため, (2)式を $n$ で 表すと $(5)$ 式のようになる。

$$
\begin{aligned}
& n=n_{1}+(1-\alpha) n_{2} \\
& n=\alpha n_{1}+n_{2} \\
& M_{2}=\alpha(1+\beta) /\left(\alpha^{2}-\alpha+1\right) \times n
\end{aligned}
$$

次に, コードマップを新規に作成するコストの割合を求 める。従来, 企業間の取引では標準コード体系や取引先コ ード体系が利用されている。取引先コード体系を利用して いる企業間では, 標準コード仲介変換方式を採用する場合, 新規にコードマップを作成する作業コストが発生し，標準 コード体系を利用している企業間では，コード直接変換方 式を採用する場合，新規にコードマップを作成する作業コ ストが発生する。従って，実際にコードマップを作成する ために作業コストが発生するコードマップ数 $M_{1}^{\prime}$ および $M_{2}^{\prime}$ は，(1)式，（5)式に対して標準コード体系の利用率 $R$ を導 入することで, 次の式のように表すことができる。

$$
\begin{aligned}
& M_{1}^{\prime}=(1-R) \times n \ldots \ldots \ldots \ldots \ldots \ldots \ldots \ldots \ldots \ldots \ldots \\
& M_{2}^{\prime}=R \times \alpha(1+\beta) /\left(\alpha^{2}-\alpha+1\right) \times n
\end{aligned}
$$

議論を簡略化するために, 牛肉業界の企業間で用いるコ ード体系は, 標準コード体系と取引先コード体系のみとす る。従って, 取引先コード体系の利用率は, $(1-\mathrm{R})$ となる。 食肉業界へのヒアリングに基づき，売り手側企業数の割

表 2 新規コードマップの必要数

Table 2. Number of new code maps

\begin{tabular}{|c|c|c|c|c|}
\hline $\mathrm{R}$ & $\mathrm{n}$ & $\beta$ & $\mathrm{M}_{1}{ }^{\prime}$ & $\mathrm{M}_{2}{ }^{\prime}(\alpha=0.8)$ \\
\hline \hline \multirow{4}{*}{0.07} & 10 & 0.5 & 9.3 & 1.0 \\
\cline { 2 - 5 } & 20 & 0.5 & 18.7 & 1.9 \\
\cline { 2 - 5 } & 50 & 3.0 & 46.7 & 13.0 \\
\cline { 2 - 5 } & 100 & 3.0 & 93.3 & 25.9 \\
\hline \hline \multirow{4}{*}{0.16} & 10 & 0.5 & 8.4 & 2.3 \\
\cline { 2 - 5 } & 20 & 0.5 & 16.8 & 4.6 \\
\cline { 2 - 5 } & 50 & 3.0 & 42.1 & 30.6 \\
\cline { 2 - 5 } & 100 & 3.0 & 84.2 & 61.2 \\
\hline
\end{tabular}

合 $\alpha$ を 0.8 とし, 複数の買い手側企業と取引する売り手側企 業数の割合 $\beta$ は, 参加する企業数に依存することから, 企 業数が 49 までのとき 0.5 , 企業数が 50 以上とき 3.0 とする。 また, 平成 17 年に実施された卸売市場の取引 EDI 化に関 するアンケート調査(14)によると, 食肉業界における標準コ 一ド体系の利用率 $R$ は 0.07 である。以上の条件から企業数 に対して作業コストが発生するコードマップ数を表 2 に示 す。表よりコード直接変換方式を採用したときに新規に作 成するコードマップ数は, 企業数が 49 以下のとき標準コー ド仲介変換方式を採用したときの約 $10 \%$ あり，企業数が 50 以上のときでも $27 \%$ と十分低いことがわかる。同時に表 2 に示すように, 仮に生鮮 4 品（青果, 水産, 花き, 食肉) のうち最も EDI 化が進んでいる青果の水準まで普及して, 標準コード体系の利用率 $R$ が 0.16 まで上がったとしても, コード直接変換方式を採用したときの方が十分低いことが わかる。以上のことから, 食肉業界では標準コード仲介変 換方式よりも, コード直接変換方式の方が, 本システムへ の適合性が高いと判断し，採用する。

〈3·2〉 コード直接変換方式図 3 に本システムのコ ード直接変換方式の処理を示す。

最初に，買い手である受信者から売り手である送信者に， 買い手側のコード体系表が送られる。送信者は, コード体 系表と送信者側のコード体系表とを比較し, 互いのコード

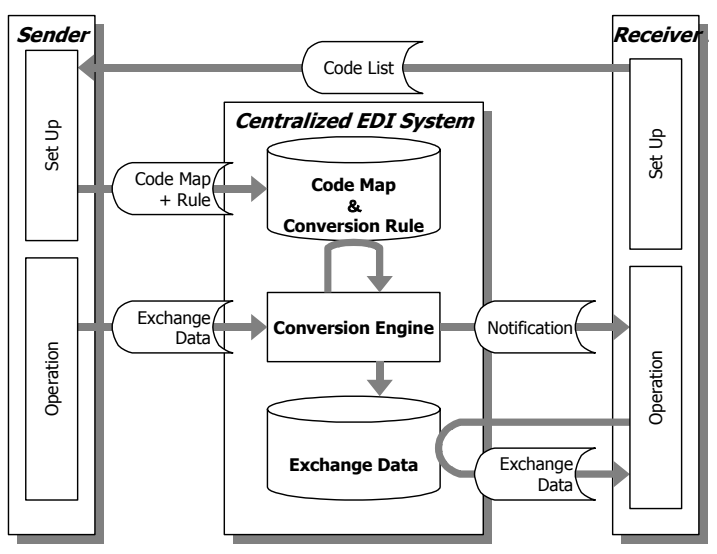

図 3 コード直接変換方式

Fig. 3. Code direct conversion function

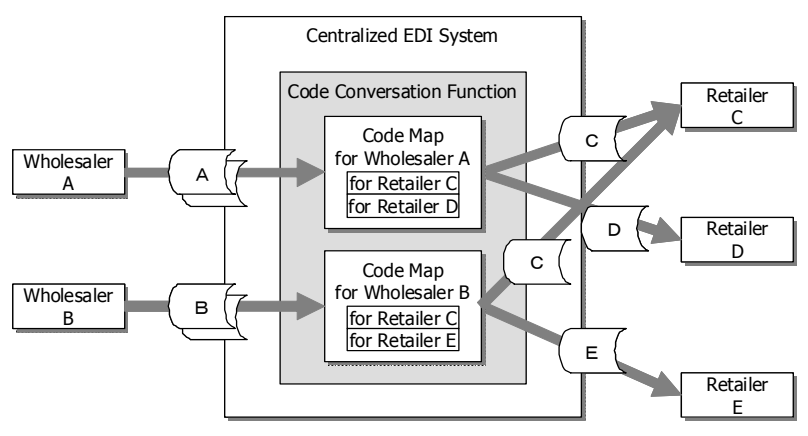

図 4 コードマップに基づくコード変換

Fig. 4. Code conversion by the code map 
体系を関連付けたコードマップを作成する。コードマップ は各コードに対して, 変換対象となる名称と, 変換される 前のコード, 変換後のコード, 変換条件で構成する。変換 条件とは, 変換前と後のコードが多対多の関係のときに, 取引情報中の他の值を組み合わせて一対一になるようにす るための条件のことを指す。

この変換条件付コードマップを一旦，データセンタ型 EDI システムに設定することで, それ以降, 送信者は送信 者側のコード体系を用いて登録すると，データセンタ型 EDI システムは, 取引情報をこのコードマップに従って変 換し, 受信者に通知する。通知を受け取った受信者はデー タセンタ型 EDI システムにアクセスして受信者側のコード 体系に変換した取引情報を取得する。

図 4 にコードマップの役割を示す。卸業者 $\mathrm{A}$ が小売業者 $\mathrm{D}$ 宛に送信した取引情報は，小売業者 $\mathrm{D}$ 用のコードマップ にしたがって変換する。小売業者 D 用のコードマップには, 変換対象の項目ごとに変換前のコードと変換後のコードと の対応表が含まれている。

〈3·3〉 コードマップの設定方法コードマップは， コードマップを作成した「送信者名」, 変換したデータの提 供先となる「受信者名」, 変換前のコードを示す「変換前コ 一ド」, 変換後のコードを示す「変換後コード」, 変換する 条件を示す「追加条件」からなる。追加条件に必要と思わ れる項目は，「食肉 EDI 標準メッセージ」が持つ 85 項目の 中の, 物流関係(6 項目), 商品関係(3 項目)または原産地(1 項目)の 10 項目とする。項目名は, 複数の設定を可能とし, AND 結合とする。一つの項目名に対して值は, 複数の設定 を可能とし，OR 結合とする。

図 5 は送信者 $\mathrm{A}$ 社が受信者 $\mathrm{B}$ 社に対して商品コード用の コードマップを設定する画面である。この画面は，変換前 のコードと変換後のコードを入力するく入力フォーム $>$ と, 多対多のコード変換を可能とするく条件設定 $>$ を備え ているのが特徵である。一対のコード変換に対して変換条 件の数は, 食肉業界の要件より五つまで設定可能とする。

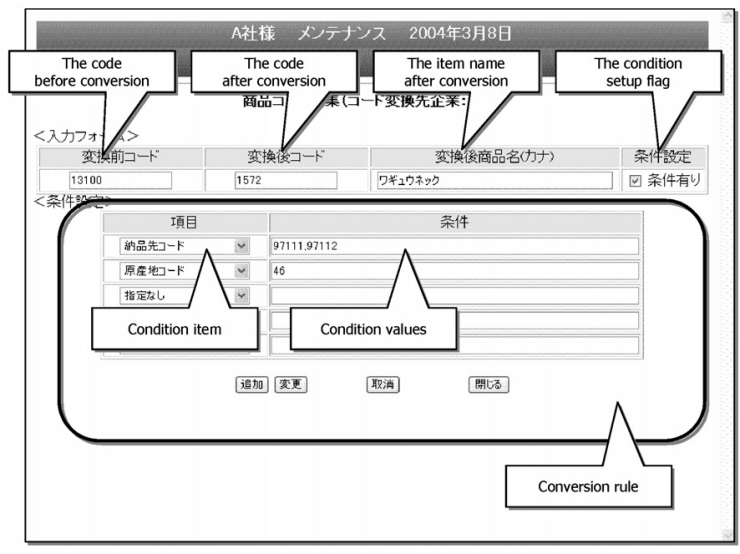

図 5 コードマップ設定画面

Fig. 5. Code conversion rule registration

\section{4. 稼動実績に基づく取引情報伝達システムの評 価}

〈4·1〉稼動実績 コード直接変換方式に基づく取引 情報伝達システムの稼動実績を表 3 に示す。2004 年 9 月か ら実運用が開始され，利用企業数は徐々に増加し，2005 年 6 月現在, 加工業者, 卸売業者, 小売業者合わせて 12 企業 が利用している。また, 本システムの稼動 9 ケ月間におけ る全登録取引情報量は, 約 160,000 件であった。表 4 は, 2005 年 6 月現在におけるコード種別ごとのコードマップの 登録数と, コード変換機能を用いて変換された変換データ 量を示している。変換データ量とは, 全登録取引情報量の 中で, コード種別に対して変換した取引情報の数を表して いる。

〈4·2〉考 察 参加企業数が 12 のとき, 必要とな るコードマップの数は，(5)式から 17.4 が求まる。本シス テムでは, 参加企業数が 12 のとき, 登録されたコードマッ プの数が 19 であり，(5)式の計算值と近い值であることが 確認できた。さらに，コードマップを新規に作成するコス トの割合は(1)'式と ( 5)'式から, 標準コード仲介変換方式を 採用した場合は 11.2，コード直接変換方式を採用した場合 は 1.2 となり, コード直接変換方式の方が優位であることが わかる。

また，全登録取引情報量が約 160,000 件に対して，本シ ステムを利用して実際に変換した取引情報量が $3 \sim 4$ 万件で あった理由も，同様に本システムを利用したコード変換の 必要がない場合であると考えられる。牛肉加工業者から卸 業者, 小売業者まで製販一体型の大手食肉関連企業は，コ ード体系が統一化されておりコード変換する必要が少ない ことが考えられる。しかし，この大手食肉関連企業と取り 引きする別企業のコード体系は異なる可能性は高く, 大手 食肉関連企業がコードの統一管理を目指す中でコード変換 機能が果たす役割は大きいと考える。

一方，表 4 に示したように，送信側企業コードと受信側

表 3 取引情報伝達システムの稼動実績

Table 3. Results of the Exchange Data Communication System

\begin{tabular}{|l|r|}
\hline Item & Data \\
\hline \hline The start & September 2004 \\
\hline Number of the company & 12 \\
\hline Transaction & 160,000 \\
\hline
\end{tabular}

表 4 コード変換処理の実績

Table 4. Results of the code conversion function

\begin{tabular}{|l|r|r|}
\hline Type of code & $\begin{array}{l}\text { Registration } \\
\text { to Code Map }\end{array}$ & \multicolumn{2}{l|}{$\begin{array}{l}\text { Conversion } \\
\text { data }\end{array}$} \\
\hline Sender Code & 19 & 31,301 \\
\hline Receiver Code & 19 & 41,923 \\
\hline
\end{tabular}


企業コードの変換に必要なコードマップ数は等しいが，変 換データ量は受信側企業コードの方が多い結果について, 以下のような理由が考えられる。值が異なる理由は，本シ ステムの仕様によるもので, コードマップは, 送信側企業 コード，受信側企業コードのどちらか一方または，両方を 変換するというように設定可能になっているからである。 受信側企業コードの变換数の方が多い理由は, 食肉業界の 流通が下流側に集中する構造になっており，送信側企業コ ードと比較して受信側企業コードを変換する処理コストが 高いことが原因だと考えられる。従って，受信側企業コー ドの方が本システムの利用数が多くなると考える。

以上の変換データ量の結果から, 従来オペレータが手動 でコード変換していたのに対し，コード直接変換機能で自 動化したため, 19 回のコードマップ登録で $3 \sim 4$ 万件分の 変換処理コストを削減したことがわかる。

また，本システムではコマンド操作と画面操作の二種類 の利用形態を用意しているが, 7 割以上のユーザは画面操作 を選択していることから本システムの操作画面には優位性 があると考えられる。現時点までクレームを受けていない ことから取引情報の入力ミスの可能性を減らしていると考 えられる。

\section{5. 結 論}

情報化がまだ途上である食肉業界において，牛肉トレー サビリティ法に容易に対応可能な企業間の取引情報伝達シ ステムとして, データセンタ型 EDI システムを適用し, 稼 動実績に基づき, その有用性を確認した。本システムは, セキュリティとアクセサビリティを考慮し，アクセス制御 機能と共通プロトコルを備え, 取引先への取引情報の伝達 や，企業本部への取引情報の一括収集を支援する。

コードマップの作成コストについて，標準コードの普及 が途上である食肉業界において，標準コードを採用する方 式より，売り手側のコードを買い手側のコードに直接変換 する方式の方が優位であることがわかった。

コード直接変換方式を適用した取引情報伝達システムは 現在も稼動中であり，ユーザ数も次第に増加しているが， これまで問題なく対応できている。コード変換機能も活用 されており，本システムは食肉業界に適用できているもの と考えられる。

(平成 17 年 8 月 24 日受付, 平成 18 年 8 月 24 日再受付)

\section{文献}

（1）農協流通研究所：「平成 13 年度食品生産・流通情報提供システム開 発・普及事業 海外調査報告書」, 農林水産省総合食料局補助事業 (2002)

(2) EAN International \& European Meat Expert Group : “Traceability of Beef", EAN International (2000)

（3）牛肉トレーサビリティ導入専門委員会：「国産牛肉トレーサビリテ イ導入手引書 (総論編)」, 社団法人 中央畜産会 (2004)

（4）杉山純一:「トレーサビリティって何?」, 日本食品出版 (2003)

（5）新山陽子：「食の安全・安心のためのトレーサビリティシステム」,

農林水産技術情報協会 研究ジャーナル, Vol.26, No.12, pp.5-11 (2003)

（6）田中庸雄・加曽利文之・加藤宽昭：「食のトレーサビリティに関す る調査研究」, 社団法人 中小企業診断協会 東京支部 (2005)

（7）食肉情報の電子伝達標準検討委員会：「国産牛肉トレーサビリティ 導入手引書 (販売業者編 : 電子伝達・記録・保存) 」, 財団法人日本 食肉流通センター (2004)

(8) W. R. Pape, B. Jorgenson, R. D. Boyle, and J. Pauwels : "Let's get animal traceback right the first time", Food Traceability Report, February 2004, pp.14-15 (2004)

(9) W. R. Pape, B. Jorgenson, D. Larson, and R. Boyle : "Selecting the most appropriate database architecture", Food Traceability Report, February 2003, pp.21-23 (2003)

（10）藤浪 啓: 「ASP 市場」, IT 市場ナビゲーター 2006, NRI 調查レポ 一ト, pp.187-194 (2001)

（11）食品流通情報化基盤開発事業：「食肉 EDI 標準メッセージ」, (財) 食 品流通構造改善促進機構（2002）

（12）総務省統計局：「平成 16 年事業所・企業統計調查」, 総務省 (2005)

（13）標淮ビジネスプロトコル変換方法調查研究アドホック TF 委員： 「標準ビジネスプロトコル変換方法調查研究報告書」, 電子商取引推 進センター (2004)

（14）生鮮取引電子化推進協議会：「卸売市場の取引EDI化に関するアン ケート調查 No.1」生鮮取引電子化推進協議会会報, 生鮮 EDI 第 29 号, pp.7-14 (2005)

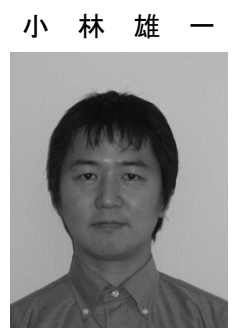

（正員） 1973 年 12 月 30 日生。 1999 年 3 月 東京大学大学院理学系研究科物理学専攻修士 課程修了。同年(株)日立製作所入社。システム 開発研究所にて, 流通トレーサビリティシステ ムにおける RFID 応用技術の研究開発に従事。

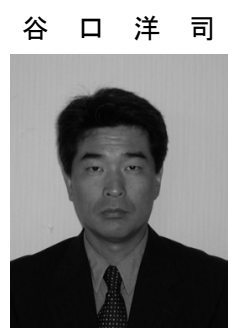

（正員） 1963 年 6 月 29 日生。 1989 年 3 月早 稲田大学大学院理工学研究科修士課程修了。同 年(株)日立製作所入社。システム開発研究所に て, 製造・流通トレーサビリティシステムにお ける RFID 応用技術・個体情報管理技術の研究 開発に従事。博士 (工学)。情報処理学会会員。

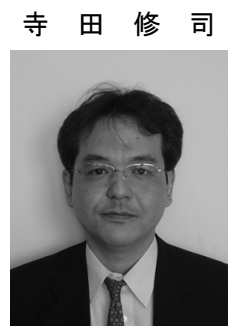

（非会員） 1963 年 6 月 7 日生。 1986 年 3 月香 川大学卒業。同年(株)日立製作所入社。トレー サビリティ\&RFID 事業部にて, トレーサビリ ティやRFIDに関わるソリューションの事業企 画に従事。

薦 田憲 久

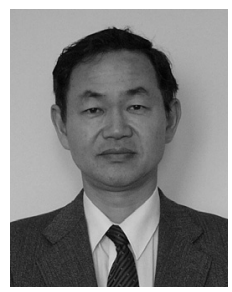

（上級会員） 1950 年生。 74 年 3 月大阪大学大 学院工学研究科電気工学専攻修士課程修了。同 年(株)日立製作所入社。システム開発研究所勤 務。91 年 4 月大阪大学工学部情報システム工 学科助教授, 92 年 8 月同大学教授。2002 年 4 月より, 同大学大学院情報科学研究科マルチメ ディア工学専攻教授。工博。ビジネス情報シス テムの研究に従事。電気学会 98 年度論文賞等 を受賞。IEEE などの会員。 